\title{
History of Origin of Tutoring in Global Educational Practice
}

\section{Chelnokova Elena Alesksandrovna}

PhD (Pedagogical Sciences), associate professor of the department of innovation management technologies Nizhny Novgorod State Pedagogical University named after Kozma Minin, Russian Federation Nizhny Novgorod; chelnelena@gmail.com

Agayev Natig Farman

PhD (Pedagogical Sciences), Associate Professor of the Department of Physical Education Nizhny Novgorod State University of Architecture and Civil Engineering

\section{Kaznacheeva Svetlana Nikolaevna}

PhD (Pedagogical Sciences), Associate Professor of the Department of Innovation Management Technologies Nizhny Novgorod State Pedagogical University named after Kozma Minin

\section{Yudakova Olga Vladimirovna}

PhD (Pedagogical Sciences), Associate Professor of the Department of Mathematics and Natural Sciences Institute of Food Technology and Design, a Subsidiary of the Nizhny Novgorod State Engineering and Economic University

\section{Blagodinova Veronika Valerievna}

PhD (Pedagogical Sciences), Assistant Professor of the Department of Theory and Methodology of the Technology and Economics Teaching, Nizhny Novgorod Institute of Education Development

\section{Spiridonova Marina Ivanovna}

Senior Lecturer of the Department of Mathematics and Natural Sciences, Institute of Food Technology and Design, A Subsidiary of the Nizhny Novgorod State Engineering and Economic University

\section{Doi:10.5901/mjss.2015.v6n6p492}

\section{Abstract}

This article represents historical analysis of origin and development of tutoring in global educational practice. Tutoring technology appeared in XI century and from then had a long road from medieval European universities of Oxford and Cambridge to global educational practice, in particular in Russia. The author of the article has done an analysis of tutor activity during the whole period of its existence: from parenting functions in XVI century to educational functions at present. The article reviews basic principles of tutor work, historical and educational meaning of tutoring as a technique of help and support of learners. The author pays special attention to retrospective review of tutoring in Russian educational system, as the author considers this technique to be the key for realisation of projects and solution of problems of modern Russian education, as well as for modernisation through a professional support in individual education.

Keywords: tutor, tutoring, tutoring technique, mentoring, medieval European universities, tutoring system, tutoring work, individual education system

\section{Introduction}

At present tutoring in the context of Russian educational scene is an innovative element. Russian system adopted it from the British one. As to the question if the tutoring can be a source for university education development at present, Rybalkina N.V. suggests to have a look at the history of universities and tutoring: "Looking at an example of more than 7century history of tutoring, we can compare it with the present situation, as well as compare our difficulties with problems 
that were present in the past" [10].

\section{2. 'Tutor': Etymology}

Reviewing the history of origin of tutoring, we should refer to the etymology of the word 'tutor'. In Russian language the word 'тьютор' derives from the English 'tutor' meaning "home teacher, coach, mentor, whose responsibilities include teaching and accompaniment of a student" (school); "supervisor of a group of students" (Eng. university), "assistance lecturer" (Amer.), "guardian" (juridical). In English language this word in its turn derives from French 'tuteur' (guardian), which in its turn comes from Latin 'tutor' from 'tuerie' (to prevent). Etymology of this word (Lat. tueor - to take care, to protect) is associated with the terms "defender", "protector", "guard". A variant of this word with a prefix in gave us the word 'intuition'.

Russian 'тьютор' (rarely 'тьютер') adopted from the English language is associated with functions of mentor, coach. However, mentoring is a tradition of American schools, based on individual work with students - usually by junior staff (post-graduate students or junior professors). Tutoring is a British tradition, based on individual work with pupils. Tutoring can be done by graduate students good at mentoring as well as by teachers. However, we should keep in mind that tutor is a special pedagogic position formed historically - it promotes development of individual educational programs for pupils and students and complements the process of individual education as school, university, during extended education and continuing education systems [Gabdulhakov, 2013].

\section{Origin of Tutoring}

Tutoring is more of a culture than a technique. It was developing parallel to culture of teaching and educating. Tutoring originated in XI century, but dates as far back as ancient Sparta: according to Andreev Yu.V. [Proskurovskaya, 2004], from the age of 7 children were living away from parents at special camps under the supervision of strict mentors, whose purpose was to raise children up as warriors through the total obeisance to seniors and development of will power. Tsukerman G.A. in her work [Tsukerman, 1997] states existence of features of mentoring system at Confucian pedagogics, though it is based on principles of student cooperation; as well as in Lancastrian system popular in Europe and America in the first quarter of XIX century. Principle of peer coaching was based on teaching of gifted boys to pass their knowledge to groups of their peers.

Tutoring as an original educational philosophy and primary way of organisation of educational system dates back to the medieval European universities of XII-XIV cent. According to Proskurovskaya I.D., tutoring as an institutionalised form of mentoring appeared at first British universities - Oxford (XII cent.) and Cambridge (XIII cent.). Main objective of those universities was educating of clergy who were basically the only literate class in Europe, participating in culture reproduction [Proskurovskaya, 2009].

Tutoring in the history of English education

In order to find out inner basis for tutoring, Proskurovskaya I.D. turns to study of "genetic" connection between tutoring and Christian monastic lifestyle: "In XI-XII centuries monasteries created the most favourable environment for development of culture and education. A shift of culture weight from monasteries to the cities clearly influenced the course of history of English scholastic education. It is well known that formation of colleges was for the most part founded by mendicant religious orders included into the university" [Proskurovskaya, 2004].

Barbagira A.A. and Fedorova N.V. mention, that tutoring system was officially declared a part of English university system in XVI century. According to the author, tutor work has following features: 1) development of individual education trajectory, person-centred communication, regular work of 1-2 students with a teacher; 2) work of 3 teachers with different functions: supervisor, moral tutor and tutor (latter performs the teaching) [Barbagira, 1979].

During following centuries tutor system began to play the main role in English university system, and lecturing was a complementary part.

University life reflected organisation of civil society (initially 'universitas' meant any public organisation or a union of people, who freely united for a common purpose or interests). A tutor used to communicate with his student not only as with a learner but also as with a friend, with a citizen. Main feature of tutor lessons was informality. Initially tutor performed the functions of a spiritual father and a mentor.

English university was a source of tutoring as it was quite different from the German type of university. The German one was oriented at an academic programme, but at the English university the student had to independently choose a way which would lead him to the knowledge needed for the degree. In such situation introduction of a tutor was inevitable: he was to take a place of an agent. Later on an agent became the main figure of the educational process. 
Proskurovskaya I.D. was studying different directions of development of naturally appeared idea of tutoring at English universities. Eventually, she arrived at a trend for a written text to acquire a function of proving. As a result, the function of a book changes, as well as its desecration, followed by rationalisation of means and methods of intellectual work and education. However, with the intellectualisation of the latter something should have been done in order to preserve the integrity of individual life and not separate the mind from the faith. It was the purpose of tutoring to promote this integrity.

Tutors in colleges stood against new fetishism of books, common for university professors and masters, trying to assert auxiliary function of a book. At a lecture a professor used to stand hidden from the students behind a book (books were quite big and usually were placed at an easel) and read the book, demonstrating an interpretation of the text. Meanwhile, a tutor gathered learners around the same book, offering them to make their own interpretation and compare it with those of other learners. Tutor implemented an idea of practical learning, helping a student to develop a skill of text interpretation, thinking and, as a result, connected discourse. Thus, a tutor, implementing a technology of text interpretation, is an agent between the cultural content of a text and individual experience of a student.

In the XVI century tutor performed mostly parenting functions, being the central figure of the university education. In the XVII century his scope of activities increases as educational functions gained more importance. Tutor helps the student to look about at initially separated content of education, offered by the university. Tutor appoints and suggests the lectures and tutorials, explains how to make a plan of studying, supervises diligent work of his students and sees if they are ready for the university exams. Tutor becomes the closest student's counsellor and assistant.

Great interest in analysis of the content and technique of tutoring in the XX century presents an authentic source study of tutoring problems by practicing Oxford tutors. Will Moore, a scientist and tutor at one of the Oxford colleges (St. John College), regards tutoring as an indisputable achievement of British education. He states that tutor is not a teacher in its classical meaning: it is not his job to transfer the knowledge, student has to look for the information on his own. In this case teacher-tutor is a constructive critic who can help sort out the information, verify it, study possible ways of work and choose one approach over others. Will Moore finishes his work by following words: "When all the resources are directed for making the education efficient... it is doubtless that there is no substitute to individual lessons with a tutor. Function of a tutor is not to teach, but to set a goal to logically and reasonably communicate their thoughts, to help the student by critically analysing and revising of his work. ..." [Palfreyman, 2001].

Other tutor - Alan Rhein - in his study "Free Learning" describes an interesting tutoring technique - method of questions: "This can surprise a perfect student: a tutor speaking only in questions. This is teaching through questions, regardless of how deep and precise the student's answers are. The purpose on the lesson is to make the student teach himself, coming to understanding of how to get out of this web of questions: "If you think that, what can you tell me about ... then?". Perfect tutor can resist the temptation to dictate the student everything he has to learn. Perfect tutor is sure that a young, clever and full of energy student would teach himself everything he should know - provided that he is asked right questions" [Ruan, 2001].

In Cambridge and Oxford universities tutors still play a critical part in educational and morale building work. Also, they occupy staff positions. At present role of a tutor is changing as relationship between a tutor and a student shift to partnering. English educators are sure that a student can evolve into an expert only under conditions of so-called close academic community, offering feedback systems between a student, a professor and the whole academic teaching staff. Here a tutor is a linchpin providing integrity of academic education [Kovaleva, 2011].

Under the present British university system a tutor performs functions of: a curator performing classes management (organisation of schedule, holding tutorials, exams, consultations, control of academic progress, academic consultations); a professor, giving practical classes (seminars), consultations on specific topic, organising individual work of students, structuring of knowledge in a specific field, supervising research term work, organising intern program; a psychologist helping solve personal problems; a facilitator promoting maximum self-expression of a student through psychological support during the studies; a distance teacher. Such composition of tutoring work assumes following means for its realisation: individual and group consultations, conversations, tutorials (weekly classes), disputes, e-mails, seminars [Chelnokova, 2011].

The main means of educating and parenting and a basic tutor's responsibility is creation of an effective individual educational program, which is subject to constant amendments and changes. Changes are made based on a joint analysis of success and advancement of a student on his path of studying. Fundamental notion of this pedagogics is a uniqueness of a human personality, of his or her purpose (including a professional one). This brings us to an individual approach to education.

During many centuries tutoring not became an anachronism of modern British education, but on the contrary took a leading position in it. Having compared historical and modern forms of tutoring systems in Britain, we can draw a 
conclusion that after a long path of development tutoring saved its basic features of mentorship and made British university education classical.

At present tutoring is actively adopted by educational systems of many countries, in particular of Russia, where tutoring is developed in several directions: from complementing of individual educational program to teaching of distance course.

\section{Tutoring in Russian Educational Practice}

In Russian educational culture the situation was different. In Russia the urban culture, characterised by free time, independence, place for personal becoming demanding communication, environment, discussion, and exchange of ideas, did not exist. The mindset was mostly oriented at peace and eternity, the forthcoming after our earthy being ends. Russia inherited German model of university, which did not suppose tutoring system.

Russian educational system initially did not have features presupposed by the German model: freedom of learning. Any German student always had a right to choose a professor, lectures and courses. Also a student had an opportunity to take chosen courses at several universities.

In 1755 - 600 years after Europe - the first university was established in Russia. By that time European universities had a system of departments with separate educational programs for every course, so Russian educational system accepted it as a given. Universities lacked local and foreign professors. The result of it was the absence of conditions for development of inner and external free space. There was no way educational movement could be supported.

Classical German system brought to Russia as it is was tested at Lomonosov University. At that time it could be described as follows: a department with pre-set programs is the core of education/bringing-up process, and professors as well as students "orbit" around it like satellites. Thus, the speed, character and way of movement within educational space are defined externally, so they do not depend on features (of a student personality and of a teacher representative of methodological institution), on uniqueness (interests, vocation, experience type) of a student. Trajectory of educational process is defined by basically the only universal tool - academic program. It is historically conditioned as German education system originated from craft guild (for example, steelmaking, pottery, papermaking etc.). The matter was to preserve and develop the crafts, and later the industries and workshop continuity. Society needed to create the most efficient way for transfer of knowledge and professional formation as quickly as possible. In this regard basic elements of classical German education system seem reasonable and rational [Chelnokova, 2011].

Russian educational system never had a separate form of tutoring. But it would be wrong to say that in Russian education were not represented the values of individualistic pedagogics as a way to develop personal responsibility for realisation of one's purpose. Mentoring techniques were used by home teachers, but in comparison to tutors they lacked corporativity and free educational space and were similar only in terms of individual approach.

Kolosova E.B. in her work "Tutor as a new pedagogical position" states: "It is early to say that in history of Russian education were not represented the values of individualistic pedagogics as a way to develop personal responsibility for realisation of one's purpose. Despite the fact that external departmental form of educational process is fully adopted from the classic German system, in Russian culture and mentality there is a number of phenomena obviously not connected with it" [Kolosova, 2008].

Here particularly we can name a tradition of monachal mentors - the starets tradition described by Fyodor Dostoyevsky in his novel "The Brothers Karamazov" (we refer to spiritual search of Alyosha Karamazov and counselling by Father Zosima).

Also we should mention governesses of the great families in pre-revolutionary Russia. Here an example of Vasily Zhukovsky would be significant: he was offered to educate the heir to the throne of the Romanov, Alexander Nikolaevich Romanov, so Vasily was deliberately and purposefully preparing for years-long teacher's work. The poet presented education program and lesson plan to the Emperor, who thoroughly studied them and approved. "The poet himself being a person of extraordinary charisma and supreme moral rectitude managed to influence the heir for good - so that now we owe to it for the great reforms of the 1860s. Nicholas I made an exceptionally successful choice of a person for education of the heir to the throne" [Liubjin, 1997].

Then, we should mention a phenomenon of classical Russian literature and its remarkable place in spiritual life and culture of Russia. This literature combines functions of philosophy, socially oriented publicistic writing and even elements of phycology. Modern Russian tutoring techniques are based upon original pedagogical tradition and were developed in line with Russian education, its problems and acute approaches.

The term 'tutor' was introduced into Russian pedagogical practice by anglophile Katkov M.N. - on January 13, 
1868 he established the Lyceum of Crown Prince Nicholas, where this position was provided. Main function of a tutor was to individually educate pupils entrusted to him. The statute of 1871 established an institute of form masters in Russia. Their responsibilities included organisational work (the control order during classes, hold meeting with teachers, maintain school documentation), as well as to watch development of learners and to foster respect for law and moral principles. In 1917 after an attempt to seamlessly combine teaching with parenting, the position of form master was abolished, so all the teachers from that moment started to work with all the children.

From 1931 a position of a group supervisor was introduced, from 1934 - of a homeroom teacher. From the beginning of 1980s there has been a promising trend (mostly by research team of Gazman O.S.) to re-introduction of a "free class teacher", which might bring the "form masters" back.

As an independent pedagogical movement in Russia, tutoring was unfolded in the end of 1980s during reforming of the whole education system. First publications upon the problem of tutoring as an independent activity appeared in our country in 1993-94 - they are mostly connected with experience in the field of distance education of the International Institute of Management LINK. This institute was a pioneer in the sphere of distance education in Russia partnering with the Open University of the Great Britain.

At present tutoring is actively introduced in educational system of many countries, including Russia. Here tutoring develops in different directions: from complementing of individual educational program to teaching of distance course.

Tutor is a special kind of teacher, who performs responsibilities of a consultant, mentor, organiser of self-directed learning and personal and professional development. In Russian system an institute of tutoring arose simultaneously with open distance professional education (ODPE), and at present it is still developing. Belitskaya E.V. has defined and described main directions of tutoring application in Russian pedagogics. Among that she mentions: organisation of clear structure of tutor educational system, spelling out of responsibilities and directions of work for tutors and learners; introduction of the most efficient and promising types of tutoring (online, for students); use of recommendations for tutors and their learners; development of guidelines for tutors by different educational institutions; use of tutoring at every stage of education etc. [Belitskaya, 2012].

Modern tutoring is based upon ideas and principles of culture-historical approach by Vygotsky L.S., of developmental psychology (theory of effective activity) by Elkonin D.B., humanitarian technological approach of philosophy and methodology, person-centred approach. At present tutoring is still at a developmental stage as to its theory and practice [Vygotsky, 2000].

Adopted from foreign countries, tutoring techniques in Russia acquired didactical attributes. Thus, a tutor should meet following requirements: open-mindedness, sense of responsibility, rapport, mental strength, as well as knowledge of complementary sciences (as a teacher), ability to shape mental personality and features of a citizen, usage of practical psychology.

\section{Conclusion}

Tutoring technique, adopted by Russia from England, is very relevant at present as realisation of modernisation projects of Russian education demands professional support of individual education of learners. Modern tutoring practice can present a source for solutions.

\section{References}

Barbagira A.A., Fedorova N.V. British Universities. Moscow: Vusshaya Shkola, 1979.

Belitskaya E.V. Tutoring System of Training in Modern Education of England. Author's thesis. Volgograd, 2012. 24 p.

Chelnokova E.A., Markova S.M. Tutor Activity of the Teacher in the Context of Vocational Training: Monograph. Nizhny Novgorod: VGIPU, 2011. P. 19-25.

Gabdulhakov V.F. Tutor as a technology for the development of creativity: Monograph. Moscow: MODEK; Kazan: Kazan (Volga region) Federal University, 2013. $250 \mathrm{p}$.

Kolosova E.B. Tutor as a New Profession in Pedagogics. Moscow: Chistye Prudy, 2008. 30 p.

Kovaleva T.M. New Profession in Russian Education - Tutor. Voprosy obrazovaniya. 2011. №. 2.

Liubjin A.I. Educating of the Heir to the Throne as Tutoring Experience. Individual-oriented pedagogics: Edited volume of the $2^{\text {nd }}$ multiregion tutoring academic conference and regional seminars. Moscow-Tomsk, 1997.

Palfreyman D. The Oxford Tutorial: Sacred Cow or Pedagogical Gem? The Oxford Tutorial: «Thanks, you taught me how to think». OXCHEPS, 2001.

Proskurovskaya I.D. Reconstruction of Historical Basis of Tutoring (Case Study of English Universities). Vestnik Tomskogo gos. universiteta. 2009. No. 2 (6). 
Proskurovskaya I.D. Revisiting the Reconstruction of Historical Basis of Tutoring. URL: http://www.thetutor.ru

Ruan, A.A. Liberal Education: and that includes the Sciences! The Oxford Tutorial: "Thanks, you taught me how to think". OxCHEPS, 2001.

Rybalkina N.V. History of Tutoring. Tutoring: Concepts, Techniques, Experience. Jubilee volume dedicated to the $10^{\text {th }}$ anniversary of tutoring conferences. 1996-2005. Tomsk: Print, 2005.

Tsukerman G. A. The One Who Teaches - Learns. URL: http: //www.experiment.Iv/rus/biblio/vestnik_3/v_zukerman_ktou4it.htm Vygotsky L.S. Psychology. Moscow, 2000. 